\title{
Nietzsche: tradição filosófica e educação
}

\author{
Nietzsche: philosophical tradition and education
}

Clenio Lago

Universidade do Oeste de Santa Catarina

\section{Resumo}

Oemergir de Nietzsche no debate filosófico e educacional contemporâneos promoveu a necessidade de uma nova rearticulação da tradição filosófica e educacional, visto que seu pensamento lança e dá força ao paradigma estético, conferindo espaço às diversidades, desde a contraposição entre Apolo e Dionisio, dois grandes princípios artísticos estruturadores da cultura ocidental. Porém, a estimulação ininterrupta pela qual descambou a estética impossibilita e até impede a sensibilidade reflexiva. Assim, perguntando sobre o impacto do pensamento de Nietzsche na tradição filosófica em meio aos desafios contemporâneos, revisitaram-se e apresentaram-se as bases e os propósitos da estética nietzscheana, as implicações na educação, evidenciando o erro em ficarmos presos a um telos previamente definido. Ao mesmo tempo, chama a atenção para a rearticulação de tais fins em meio ao dinamismo da realidade, tornando imprescindível a dimensão estética como condição humana.

Palavras-chave: Nietzsche. Tradição filosófica. Educação.

\section{Abstract}

The emergence of Nietzsche in contemporary educational and philosophical debate promoted the needing for a new re-articulation of the philosophical and educational tradition, since his thinking gives strength to the aesthetic paradigm, giving space for diversity, since the opposition between Apollo and Dionysus, two major artistic principles that structure the Western culture. However, the continuous stimulation by which has the aesthetic descended makes it difficult or even impossible for the reflective sensitivity. Thus, asking about the impact of Nietzsche's thought on the philosophical tradition among the contemporary challenges, the bases and purposes of Nietzschean aesthetics were revisited and presented, their implications in education, highlighting the error in being trapped in a predetermined telos. At the same time, it draws attention to the re-articulation of these ends amid the dynamism of reality, making imperative the aesthetic dimension as human condition.

Keywords: Nietzsche. Philosophical tradition. Education. 


\section{Introdução}

Diante do dinamismo da vida, os gregos se perguntavam por referenciais que possibilitassem certezas, seguranças às ações. Instituíram a metafísica como um lugar fora da areia movediça da contingência, situação em que os valores passaram a ser alcançados e delineados pela razão, ficando a experiência sensível a esta subordinada. Nos medievais, subsumidos na teologia, como telos educativo, na forma de crença em Deus justificada aos moldes do modelo neo-platônico, também estão no horizonte da metafísica.

Os ideais éticos gregos buscam a plena e perfeita realização humana, a ser obtida pela razão, enquanto que a tradição cristã traz ideais em que o homem depende totalmente de um Deus único e criador, que se revela como verdadeiro fim. A ética cristã encontra em Jesus Cristo o modelo absoluto de perfeição humana. (HERMANN, 2001, p. 30).

Com a crise do paradigma medieval e do ideal de homem divino, busca-se, no homem, na razão objetiva, ou seja, na razão científica, o novo referencial de certeza. Este, constituído no âmbito do sujeito transcendental como razão pura, abandona as causas contingentes para, a partir de si, postular os referenciais, as causas transcendentais. Agora, o sujeito do conhecimento deve aparecer no processo com sua universalidade, deixando de lado suas particularidades, a contingência, ou, no máximo, subordinando-as à razão. Mas os efeitos históricos da razão pretensamente pura, aos poucos, mostram-se não tão razoáveis. Entra em crise a razão moderna, revelando-se com ela os limites do sujeito moderno e de suas certezas. Consequentemente, os limites do ideal de homem racional sob o qual se estruturou o mundo ocidental e as compreensões de educação decorrentes. "Desde o pensamento platônico até o século XIX, a filosofia estabeleceu um fundamento para educação e sob tais fundamentos, definiu os chamados fins éticos [...]" (HERMANN, 2001, p. 21), ou seja, o ideal de homem racional, aquele capaz de, com base no uso da razão, chegar à verdade.

Essa crise está sinteticamente expressa no pensamento de Nietzsche, que, em meio à decadência da cultura europeia, ao niilismo do paradigma ocidental, diagnostica que o paradigma da racionalidade pura estava sufocando o ser, não mais sendo possível permanecer em tal estrutura. Assim, 
considerando que o pensamento moderno caracteriza-se por sua estruturação lógico-matemática, em A gaia ciência, Nietzsche se pergunta:

De onde surgiu a lógica na mente humana? Certamente do ilógico, cujo domínio deve ter sido enorme no princípio. [...] Mas a tendência predominante de tratar o semelhante como igual - uma tendência ilógica, pois nada é realmente igual - foi o que criou todo fundamento para a lógica. [...] por muito tempo foi preciso que o que há de mutável nas coisas não fosse visto nem sentido. (NIETZSCHE, 2005, p. 139).

Ao expor a lógica estrutural da racionalidade moderna como sendo ilógica, Nietzsche elucida o centro nuclear da modernidade como um particularismo tomado como abstrato e universal, desde uma vontade de poder. Vale ressaltar que não foi suficiente evidenciar a lógica da lógica como sendo ilógica. Nietzsche precisou implodir o referencial conceitual de perfeição, Deus, a filosofia como moral. O anúncio da morte de Deus, o trazer à consciência desse feito foi o grande passo para ultrapassar o niilismo, quando na voz do homem louco que, em plena luz do dia, vai ao mercado e grita incessantemente:

Procuro Deus! Procuro Deus! [...] $\bigcirc$ mais forte e mais sagrado que o mundo até então possuíra sangrou inteiro sob os nossos punhais [...]. Nunca houve um ato maior - e quem vier depois de nós pertencerá, por causa desse ato, a uma história mais elevada que toda a história até então! (NIETZSCHE, 2005, p. 147-148).

Nietzsche sabe que não é o único responsável pela morte de Deus, a morte do princípio moral "tu deves", mas o que dá-se conta de que o paradigma vigente está em ruínas e que era preciso novos referenciais. Mais do que isso, é aquele que se aventura para além do paradigma racionalista. Dessa forma, Nietzsche coloca em questão tanto a crença na origem divina da verdade como o seu valor absoluto e universal, por decorrência, o modo metafísico de pensar. ${ }^{1}$

Nietzsche evidencia "[...] o caráter fictício da própria moral, da religião e da metafísica e o desencanto é a tomada de consciência de que não há estrutura, leis e valores objetivos." (HERMANN, 2001, p. 73). A ruptura da metafísica implica compreender que não mais existe verdade absoluta, modelos ideais, mas possibilidades, perspectivas, ou seja, interpretações. "Não 
existe Coisa-em-si, nenhum conhecimento absoluto; o caráter perspectivista, ilusório, enganador é intrínseco à existência." (NIETZSCHE in MARQUES, 1989, p. 77). E, nesse sentido, o 'Eu' trata-se [agora] de uma hipótese auxiliar com vista à inteligência do mundo." (NIETZSCHE in MARQUES, 1989, p. 73). Sendo assim, Nietzsche (apud MARQUES, 1989, p. 88) se pergunta: "Em que pode unicamente consistir o conhecimento? 'Interpretação', de modo algum 'explicação'." Para Nietzsche, não há fatos em si, verdade, somente interpretação. $O$ que constitui a radicalidade de seu pensamento é o perspectivismo, a ausência de um telos, a realidade como possibilidade dinâmica.

$\bigcirc$ questionamento da verdade como algo "em si" efetivado por Nietzsche destituiu o referencial do "eu pontual" postulado por Descartes², o eu transcendental kantiano, bem como a ideia de espírito absoluto apresentado por Hegel, obrigando a filosofia incorporar o problema da contingência e da aparência há muito desvalorizados no discurso filosófico. E, ao mesmo tempo evidenciou a necessidade de superar o medo da diferença presente na tradição ocidental, através do ideal de objetificação do outro.

Assim, o anúncio da morte de Deus abalou os fundamentos objetivos e subjetivos da modernidade, a ideia de verdade e de sujeito. Ensejou o ressurgimento da experiência do trágico, colocando no lugar do "tu deves" o "eu quero", a afirmação da vida e a moral como criação perspectiva em que o homem é a própria obra de arte se fazendo arte. Assim, visto que "a grandeza do homem está em ser ele uma ponte, e não um fim: o que se pode amar no homem é que ele é uma passagem e um crepúsculo." (NIETZSCHE apud GIACOIA JÚNIOR, 2000, p. 58).

Agora, a exigência é que o homem precisa orientar sua vida a partir de novos valores que não sejam os já estabelecidos culturalmente e dados como prontos e imutáveis. É preciso, acima de tudo, partir daqueles princípios que estejam voltados à afirmação da vida, para além da moral de rebanho, para além do bem e do mal. Nesse sentido, não é suficiente reconhecer e romper com passado, com a tradição que impõe o "tu deves", é preciso o sim afirmativo da criança.

A criança é a inocência, e o esquecimento, um novo começar, um brinquedo, uma roda que gira sobre si, um movimento, uma santa afirmação. Sim; para o jogo da criação, meus irmãos, é necessária uma santa firmação: o espírito quer agora a sua vontade, o que perdeu o mundo quer conseguir o seu mundo. (NIETZSCHE, 1985, p. 211. 
É preciso ser espírito livre, liberado como o espírito da criança que manifesta com sinceridade seus desejos, suas simpatias e antipatias. Isso porque, para Nietzsche, a racionalidade ocidental, configurada a partir de Sócrates e centrada na arte apolínea, perdeu a capacidade de criar valores adequados ao tempo histórico, por se efetivar demasiadamente formal e atemporal. Nietzsche é aquele que se aventura para além do paradigma vigente, para além da metafísica.

A crise que chamamos de crise da modernidade é, na verdade, a crise do modo metafísico de pensar dualista que separa sujeito do objeto, homem da natureza, teoria da prática, o formal do sensível, aquele que sabe daquele que não sabe, professor do aluno. É a crise do ideal de homem racional, tido como fim último, da razão pura como garantidora da verdade. Em educação, é a crise do telos, do referencial, do ideal educativo articulado em torno do ideal de homem racional.

Para melhor elucidar o significado dessa crise, bem como seus impactos para a educação, percorremos as argumentações de Nietzsche como forma de trazer presente a estruturação do paradigma estético visto evidenciar que, se existe uma justificativa da existência para Nietzsche, ela deve ser

184 estética. E atualmente, com a ressonância de que tudo passa a ter sentido, validade, se esteticamente configurado. (WELSCH, 1995).

\section{A arte em Nietzsche}

Na formação da cultura ocidental, o "mito da caverna", apresentado em A República, é o grande sinalizador do lugar ocupado pela obra de arte e, juntamente com esta, da experiência estética, servindo de referencial às ações educativas. É especialmente com Platão (2004) que é projetado o ideal de homem racional, aquele que subordina seus instintos, seus desejos à razão, ou seja, aquele que deve agir racionalmente. Nesse contexto, os sentidos, a experiência sensível ou é desqualificada como sendo de pouca importância, ov é articulada desde a racionalidade como uma faculdade secundária, o que faz da obra de arte, da experiência estética, uma experiência de pouco valor no processo de formação. Isso porque a obra de arte, sendo representação da representação, não mostraria a realidade em sua essência, senão que a desvirtuaria. Embora guiado pelo viés objetivista, porque centrada no objeto, 
a atualidade da postura platônica está na cautela que devemos adotar em meio ao paradigma estético (TREVISAN, 2000), o que, a partir de Nietzsche, é visível para com o paradigma racionalista.

Embora o Renascimento tenha sido marcado por uma profunda retomada da arte, é, na modernidade, que a estética, especialmente com Kant (2008), na obra Crítica da faculdade do juízo, assume dimensão essencialmente subjetiva, centrada no juízo do gosto e não mais nas qualidades do objeto. Contudo, quem toma e desenvolve a estética como o carro chefe de toda a proposta educacional, como uma dimensão autônoma é Schiller (1991) ao buscar, através do impulso lúdico, superar o homem fragmentado.

Schiller propôs uma "Educação estética da humanidade" através da articulação entre os impulsos formal e sensível, sinalizando que o homem é pleno enquanto joga. Porém, a dimensão estética ganha força e aparece com status de paradigma a partir da ruptura da metafísica realizada por Nietzsche que, na voz do homem louco, anuncia a morte de Deus. E esse feito acabará por ter profundos impactos na educação, uma vez que afetou o referencial de homem racional, o ideal de verdade absoluta, em suas essências, liberando as experiências estéticas, antes cooptadas, engessadas a tais referenciais. Ou seja, a estética ganha autonomia, para, logo mais, se impor como referencial.

Nietzsche, desde a estética, realiza o diagnóstico dos limites da racionalidade moderna, do niilismo do paradigma ocidental, cujas raízes estariam no Sócrates platônico. Também se serve da estética, da experiência artística como forma de ultrapassar o último homem e perguntar pelo Além-do-Homem ${ }^{3}$ - Sua proposta remonta à tragédia grega, apresentando a arte dionisíaca em contraposição ao princípio da arte apolínea. $\bigcirc$ elemento dionisíaco como a mola propulsora e não o elemento apolíneo, ou pelo menos no jogo profundo entre estes. "[...] Dionísio revela uma visão de mundo que é trágica em sua essência [...]" (AZEVEDO, 2010, p. 18), o espírito livre, liberado das amaras morais.

\section{10 princípio artístico apolíneo}

Nietzsche, em sua leitura sobre a arte na cultura ocidental, afirma que esta, ao celebrar Apolo, o deus da ordem, esteve marcadamente estruturada pelo ideal apolíneo e esquecera a arte em sua dimensão dionisíaca. 
Esse esquecimento teria levado ao esvaziamento do ser e da arte enquanto formação, por esta haver ficado atrelada ao objetivismo e ou ao subjetivismo estético. Assim, Nietzsche, em A visão dionisíaca de mundo, e também em $\bigcirc$ nascimento da tragédia, parte da crítica à arte apolínea para, depois, abordar a arte dionisíaca, na diferenciação com esta. Já em Assim falava Zaratustra, conforme Barros (201 1), há o ressurgimento do trágico e da inspiração dionisíaca à semelhança dos gregos, sinalizando que, embora houvesse variações nas temáticas abordadas no decorrer de sua obra, Nietzsche permaneceu fiel à estética. Nesse sentido, reportamos-nos à compreensão estética estruturadora de seu pensamento.

Nas palavras de Nietzsche:

Os gregos, que nos deuses expressam e ao mesmo tempo calam a doutrina secreta de sua visão de mundo, estabeleceram como dupla fonte de sua arte duas divindades, Apolo e Dionísio. $\bigcirc$ homem alcança em dois estados o sentimento de delícia, a saber, no sonho e na embriaguez. [...] Mas em que sentido Apolo pôde se tornar uma divindade artística? Somente na medida em que é o deus da representação onírica. Ele é o 'aparente' por completo: o deus do sol e da luz na raiz mais profunda, o deus que se revela no brilho. A 'beleza' é o seu elemento: eterna juventude o acompanha. Mas também é o seu reino a bela aparência do sonho: a verdade mais elevada, a perfeição desses estados, em contraposição à realidade diurna lacunarmente inteligível, elevam-no a deus vaticinador, mas tão certamente também a deus artístico. (NIETZSCHE $2005 a$, p. 51

Com base na bela aparência, a arte apolínea vem estabelecer o jogo com o sonho e somente como representação onírica faz-se divindade artística representada como idealização. A partir da arte plástica, o homem expressa a realidade do sonho no qual o homem individual joga com o real desde o ideal.

Na arte apolínea, a razão está como o princípio mais elevado e a estética como expressão da razão no sensivel é o ápice dessa expressão. Assim, o homem que, em sonho, realiza seus mais profundos desejos, através da arte plástica materializa o que até então era imaterial e estava no âmbito da imaginação. Se o sonho é o jogo com a realidade, a arte apolínea é o jogo com o sonho. Assim, em sua arte, no princípio apolíneo, é expressa a 
imagem idealizada do sonho tendo a perfeição como característica. É nesse sentido que:

culto às imagens da cultura apolínea [...] tinha seu fim sublime na exigência ética da medida, que corre paralela à exigência da beleza [...] o limite que o grego tinha que observar era o da bela aparência. A meta mais íntima de uma cultura voltada para a aparência e a medida não pode ser senão o velamento da verdade: o limite que o grego tinha que observar era o da bela aparência. (NIETZSCHE, 2005a, p. 22).

Na arte Apolínea, com base na razão, o homem alcançava o mais alto prazer na contemplação das ideias, passando despercebido ao artista apolíneo a incompletude do prazer a esta condicionada, bem como a dimensão singular dessa experiência estética assegurada por um ideal posto. Lógico que esse princípio estético tem sentido em meio aos desmandos dos impulsos, dos instintos, das paixões, na medida em que serve de base a organização da polis.

Como toda forma de expressão artística, a arte de princípio apolíneo não deixava de exercer seu papel de amenizar a dor da existência, pois, através da razão, o mundo estava artificialmente protegido. Isso porque, na estética como expressão da obra supostamente perfeita, o artista alcançava a glória ao evidenciar um comportamento ideal. Bastava ser belo e perfeitamente sob medida, para tornar real o sonho, visto que, pelas mãos do artista, a obra ganha forma, o sonho torna-se realidade, se materializa. Nesse sentido, a arte constitui-se como representação e personificação do ideal que, em Platão, é a correta representação do mundo das ideias.

Mas tendo em vista que os desejos da vontade estão ligados ao belo e ao horripilante que também se reflete prazeroso no onírico, na arte apolínea o horripilante também se tornava belo, como a desmedida quem impele para a medida. Dessa forma, é de se esperar de uma arte e da educação, proveniente do deus da bela aparência, o controle mediante um processo de formação voltado para um telos definido. E, assim, a exigência da perfeição da medida se propagou, chegando ao topo da pirâmide artística. Isso culminou na necessidade de uma nova expressão artística, uma vez que, na arte apolínea, o ser somente pode ser encarado como medida, sob a regra, esquecendo-se do "não-ser", cuja dimensão pode ser visualizada e experienciada 
nas várias manifestações artísticas, no caso dos gregos, especialmente nas tragédias, como condição à existência.

\subsection{0 princípio artístico dionisíaco}

Em meio à idealização estética da medida, Dionísio, em As bacantes de Eurípedes, convence Penteu ao se vestir de mulher e participar do ritual das bacantes. Mas percebido como intruso, é arrancado de seu lugar seguro sendo sacrificado pela própria mãe, que, em meio ao ritual, diz: "a cabeça de Penteu eu seguro, ó desventurada". (EURÍPEDES, 2010, p. 52). Sobre o assunto, afirma Nietzsche:

Em um mundo construído desta maneira e artificialmente protegido penetrou então o som extático da celebração de Dioniso, no qual a inteira desmedida da natureza se revelava ao mesmo tempo em prazer, em sofrimento e em conhecimento. Tudo que até agora valia como limite, como determinação de medida, mostrou-se aqui como uma aparência artificial: a 'desmedida' desvelava-se como verdade. (NIETZSCHE, 2005a, p. 23).

No culminar do exagero em sua exigência, a arte apolínea decai, a arte em sua dimensão dionisíaca emerge e o jogo estético aparece. Surge, então, a arte de princípio dionisíaco, conferindo espaço a novas formas de expressão. Com Dionísio, dança o mundo e, em sua dança, o mundo munda, como possibilidade, fazendo-se não mais com base em modelos prévios, mas em perspectivismos. Não há mais uma medida correta, exigências universais. A razão é substituída pela força afirmativa da vida, que reclama o ser, a fidelidade à terra. Aqui, o belo e o horripilante se unem, as castas se dissipam no mesmo coro. A arte dionisíaca surge para reabilitar não somente a relação profunda entre os homens, mas também a relação entre o homem e a natureza.

Tudo o que até então foi desconsiderado pela razão, agora é tido como forma de expressão da vida na arte Dionisíaca. $\bigcirc$ mundo imaginário, antes expresso através da arte plástica, agora é sentido/vivido, experienciado. A própria existência emerge como dimensão estética na estética da existência. Não há mais limites para a Vontade, não há padrões, nem medidas. $O$ ser fica liberto, liberado das amarras morais. $\bigcirc$ diverso, o diferente, o estranho vivenciados de uma só vez. $\bigcirc$ (des)limite é aqui cultuado como o ser que, ao 
se liberar, se efetiva. Assim, diferentemente da arte apolínea, que repousa no jogo com a lucidez,

A arte dionisíaca [...] repousa no jogo com a embriaguez, com o arrebatamento. São dois os poderes que principalmente elevam o homem natural ingênuo até o esquecimento de si característico da embriaguez, a pulsão da primavera (frülingstrieb) e a bebida narcótica. Seus efeitos estão simbolizados na figura de Dioniso. $\bigcirc$ principium individuationis é rompido em ambos os estados, o subjetivo desaparece inteiramente diante do humano-geral, do natural-universal. (NIETZSCHE, 2005a, p. 8).

No princípio apolíneo, a vontade se expressava através da representação materializada do sonho. Na arte dionisíaca, a Vontade se expressa como o próprio acontecimento. Sob o efeito da bebida narcótica, durante as festas dionisíacas o eu individual desaparece em meio às vivências desmedidas e à irrupção do humano-geral. É o próprio acontecer temporal. Não há mais distinção entre os opostos, nem idealização do perfeito, ao passo que tudo é vivência e a vivência é expressão artística, a experiência ampla do ser em acontecimento.

Também, aqui, a expressão corporal é vivenciada através da pulsão da primavera como expressão afirmativa da vida, momento em que a força gerativa da vontade na natureza se faz sentir, sobremaneira. Tanto na embriaguez, quanto na pulsão da primavera, o que emerge é a expressão criativa: um homem novo, novos valores. A criação é o maior bem do artista dionisíaco a desbordar o ainda não em contraposição à arte Apolínea, na qual o referencial é a perfeição da representação e a idealização da imagem-forma. A criação é o mais alto nível de sua arte.

[...] as festas de Dionísio não firmam apenas a relação entre os homens, elas também reconciliam homem e natureza. Voluntariamente a terra traz os seus dons, as bestas mais selvagens aproximam-se pacificamente: coroado de flores, o carro de Dionísio é puxado por panteras e tigres. Todas as delimitações e separações de casta, que a necessidade (Not) e o arbítrio estabeleceram entre os homens, desaparecem: o escravo é homem livre, o nobre e o de baixa extração unem-se no mesmo coro báquico. Em multidões sempre crescentes o evangelho da "harmonia dos mundos" dança em rodopios de lugar para lugar: cantando e dançando, expressa-se o homem como membro de uma comunidade ideal mais elevada: 
ele desaprendeu a andar e a falar. Mais ainda: sente-se encantado e tornou-se realmente algo diverso. Assim, como as bestas falam e a terra dá leite e mel, também soa a partir dele algo sobrenatural. Ele se sente como deus: o que outrora vivia somente em sua força imaginativa, agora ele sente em si mesmo. $\bigcirc$ que são para ele agora imagens e estátuas? $\bigcirc$ homem não é mais artista, tornou-se obra de arte, caminha tão extasiado e elevado como via antes os deuses caminharem. (NIETZSCHE, 2005a, p. 8-9).

Agora, radicaliza-se a autodeterminação individual como referência sobre o bem e o mal. A vontade é apresentada como soberana de si no lugar da razão, como o impulso básico a novos valores. É eliminada a representação concebida idealmente na arte apolínea que, desde a arte milimetricamente concebida, exigia e assegurava um horizonte à educação, um telos. Em seu lugar, assume a arte dionisíaca, a arte vivencial. A vontade é apresentada como soberana de si no lugar da razão, como o impulso básico a novos valores. A medida transforma-se me desmedida, para, depois, emergir como nova medida e sucessivamente desmedida. É eliminada a representação concebida idealmente na arte apolínea esta que, desde a arte milimetricamente concebida, exigia e assegurava um horizonte, um telos à educação. Em seu lugar, assume a arte dionisíaca, a arte vivencial, como autonomia estética. Dessa forma, o modo de ser passa a ocorrer no arrebatamento artístico da desmedida dionisíaca, que conjuga o sensível e o formal na aparência ${ }^{4}$, como experiência estética sendo possível criar novos valores. Assim, o homem é a própria arte se fazendo arte na conjugação entre lucidez e embriaguez ${ }^{5}$. Expressando-se na relação com o mundo e com os outros indivíduos, criando nova realidade, na qual o todo não é apenas a soma das partes, é formado por algo mais elevado. E o homem que, antes, assistia ao jogo com a arte, agora se eleva acima de si entrando no jogo, vivendo o jogo criativo. $\bigcirc$ artista entra em jogo, ele faz o jogo e é nele jogado: é o material nobre a ser talhado, o ser em devir.

Em Assim falava Zaratustra, tem-se o fruto mais poderoso. Para além do jogo dual entre Apólo e Dionísio na tragédia grega, a arte assume a dimensão criadora, pelo personagem trágico: Zaratustra.

Assim falava Zaratustra, fora concebido segundo a perspectiva trágica, para o que a arte criadora e afirmativa é posta como necessidade. $\bigcirc$ ressurgimento do trágico e da inspiração dionisíaca aproxima o conteúdo de Assim falava Zaratustra de pressupostos 
gregos que Nietzsche já utilizava em seu primeiro livro, no qual os helenos são descritos como um povo de cultura fundamentalmente artística, que teria chegado ao fim graças à crítica racional do seu caráter ideal. (BARROS, 2011 , p. 117).

A aposta na arte dionisíaca que, diferentemente da arte apolínea, "[...] repousa no jogo com a embriaguez, com o arrebatamento" (NIETZSCHE, 2005 a , p. 8) possibilita a compreensão do homem como a obra de arte em processo, como autoformação. $\bigcirc$ jogo é o jogo com a embriaguez, no qual o artista também joga com a natureza, com os seres e consigo mesmo. $\bigcirc$ jogo da arte dionisíaca é o jogo no qual o homem se faz obra e é artista de si mesmo no passo em que se relaciona com o outro em sua comunhão vital. $\bigcirc$ artista eleva-se acima de si. Ele compreende o jogo, compreende-se na angústia do sentimento de total expressão do mais íntimo do seu ser, através da embriaguez que, por momentos, trouxe-lhe a delícia da existência, fazendo-a existir em sua afirmação.

\section{O impacto de Nietzsche na tradição filosófica ocidental}

Desde o surgimento de Nietzsche no cenário filosófico, várias foram as avaliações sobre o pensamento nietzscheano, desde condenações sumárias como ateu, a-moral, degradante até aceitações incondicionais como a filosofia, em virtude da radicalidade do seu pensar. Então, desde a negação à aceitação incondicional, o pensamente de Nietzsche não pode ser compreendido em seu grande propósito. Porém, embora se tenham, hoje, leituras mais significativas do conjunto da obra filosófica de Nietzsche, da sua escrita com base em aforismos, certamente é um pensar ainda produtivo, uma vez que "[...] Nietzsche atacou frontalmente o princípio idealista da autoconsciência, dizendo com um olhar retrospectivo a Descartes: 'É preciso duvidar de maneira mais fundamental'. Tomar os enunciados da autoconsciência por dados parece-nos, desde então ingênuo." (GADAMER, 2007, p. 15).

De forma mais explícita, o questionamento de Nietzsche não somente dirigido ao cogito cartesiano, ao paradigma estruturador do modo ocidental de pensar que se encontra configurado em Descartes que concebe o homem composto de res cogitans e res extensa, duas substâncias diversas, sendo a res cogitans a definidora do homem e os sentidos algo enganador. "O que 
está sendo questionado aqui, é a distinção entre corpo e mente. [...] Para Nietzsche, ao contrário, não há separação entre o fisiológico e o psicológico" (ITAPARICA, 2000, p. 71-72), sendo o corpo uma estrutura social de instintos e afetos. A partir de Nietzsche, não é o pensamento uma instância puramente lógica, visto a lógica ter surgido, "[...] certamente do ilógico [...]." (NIETZSCHE, 2005, p. 139). O pensar de Nietzsche afeta, questiona o paradigma filosófico moderno em sua essência, centrado na crença da lógica e a compreensão de verdade como correspondência em seu fundamento moral. Com essa radicalidade

Nietzsche impõe ao caráter filosófico a exigência de exame da procedência genealógica do "verdadeiro" do 'simples', do 'desinteresse', etc. $O$ aspecto imprescindível disto deriva do fato de a reflexão filosófica ainda continuar sendo conservação de valor criado, de valor efetivado. Situação que abrange, desde as mais antigas formas e apelos, até a simples idéia de 'bom gosto' com que a 'razão' se traveste para impor e dominar. (NASCIMENTO, 1998, p. 37).

Nesse sentido, o trágico figura como conteúdo da relação vida e pensamento, como a existência sendo pensado como transcendência.

A partir de Nietzsche percebe-se que o nível mais alto que a filosofia alcança é o de questionar-se sobre o que ela pode ser. Este poder significa poder obter a verdade, experimentando-se até que ponto ela obedece à vontade de verdade. (NASCIMENTO, 1998, p. 38).

Ou seja, a atividade do pensar não existe fora da ação e intimidade dos instintos, existindo a verdade apenas como cumplicidade entre o sensível e o suprassensível, reclamando à filosofia a necessidade de teorizar para a vida a partir da falta de equilíbrio da existência, do caráter trágico da existência, visto a vida não ter sido inventada pela moral. Assim, sua crítica à moral é uma crítica à filosofia que, como moral, subjugou os instintos a essa. No sentido estrito de telos, a vida é vontade de potência e, enquanto tal, não tem uma finalidade determinada: um acolher do devir. Do contrário, a filosofia "[...] torna-se radical e incondicionalmente a própria moral." (NASCIMENTO, 1998, p. 391. 
Avaliando a estrutura do pensamento de Nietzsche e o impacto desse pensamento, Habermas afirma que Nietzsche altera radicalmente a lógica do discurso moderno, pois "[...] entroniza o gosto 'o sim e o não do palato' como o único órgão de um 'conhecimento' além do verdadeiro e do falso, além do bem e do mal. Eleva o juízo do gosto do crítico de arte a modelo de juízo de valor, de 'valoração'". (HABERMAS, 2002, p. 176, grifo do original). Agora, é o gosto, e não mais a razão, a referência de certeza, de valoração à autonomia. $\bigcirc$ fundamento estaria na aparência, na satisfação desinteressada da perspectiva dos espectadores e não mais no entendimento. É o artista genial que cria valores através do olhar que dita valores ${ }^{6}$. Dessa forma, conforme Habermas (2002), a ruptura da individuação e da racionalização torna-se a via para escapar da modernidade, pois o niilismo radical abre o mundo como um tecido de dissimulações e interpretações, como possibilidades. Nas palavras de Giacoia Junior (2008), Nietzsche, com base no fio condutor da razão histórica, radicaliza o contraesclarecimento, o esclarecimento per(verso) reabilitando o mito. Vale-se do esclarecimento para, mais adiante, deixá-lo de lado, visto entender que a razão que se arvorou como liberdade tornou-se prisão, a fonte da individuação.

Ainda conforme Habermas (2002), Nietzsche desenvolveu a teoria da vontade de poder ${ }^{7}$, explicando, assim, o surgimento das ficções do mundo, as ideias de bem e de mal, a própria ideia de sujeito moderno como expressão da ideia de que o ser vivente é uma vontade de poder. Dessa forma,

[...] com a entrada de Nietzsche no discurso da modernidade, a argumentação altera-se radicalmente. Primeiro, a razão fora concebida como autoconhecimento reconciliador, depois como apropriação liberadora e, finalmente, como rememoração compensatória, para que pudesse se apresentar como poder equivalente da religião e superar as cisões da modernidade a partir das forças motrizes da própria modernidade. Por três vezes falhou essa tentativa de talhar um conceito de razão segundo o programa de um esclarecimento em si mesmo dialético. Nessa constelação, Nietzsche tinha apenas a escolha de submeter, mais uma vez a razão centrada no sujeito a uma crítica imanente ou abandonar por completo o programa. Nietzsche decide-se pela segunda alternativa. Renuncia a uma nova revisão do conceito de razão e despede a dialética do esclarecimento. [...]. É certo que Nietzsche aplica mais uma vez a figura de pensamento da dialética do esclarecimento ao esclarecimento historicista, mas com o objetivo de romper 
o indivíduo racional da modernidade enquanto tal. Nietzsche utiliza o fio condutor da razão histórica para ao cabo descartá-la e fincar o pé no mito, o outro da razão. (HABERMAS, 2002, p. 124125 , grifo do original).

Ao colocar o deus Dionísio no lugar do deus Apolo, o outro da razão como o deus articulador, arte dionisíaca no lugar da arte apolínea em que o homem é obra de arte, o que se coloca, em definitivo com Nietzsche é a perspectiva da estética ante a razão, lugar de onde efetiva o diagnóstico da época e funda sua proposta. Assim, no lugar do paradigma racional, instala-se o paradigma estético. Mas isso não significa dizer que o debate se encerra. Muito pelo contrário, o debate apenas se abre, pois ao efetivar a passagem do paradigma da razão para o paradigma da estética, abriu um caminho pouco ou quase nada trilhado, senão, muitas vezes, ignorado e/ou desprezado em sua importância pela cultura ocidental até então. Por conseguinte, a estética que, desde Platão até os limites da modernidade, ocupou um lugar secundário em relação às questões de fundamentação ou de definição de bem-viver, com Nietzsche passa a ocupar lugar central como a medida sem medida, a grande e única justificativa da existência, se é que existe justificativa. (HERMANN, 194 2004).

Já autores considerados pós-modernos radicalizam o pensamento de Nietzsche, incorporando a radicalidade do seu pensar, acreditando que o passado já passou, que a tradição não teria mais nada a dizer, lançando-se, apostando no perspectivismo ${ }^{8}$. Para esses autores, a radicalidade inclui a negação da tradição pela compreensão de que a tradição teria inviabilizado o ser. Porém, cabem algumas perguntas para não ficarmos presos às posturas tradicionais que se digladiam em acusadores e defensores de Nietzsche esquecendo-se da diferença entre disputa e diálogo: é possível a proposta de Nietzsche constituir-se em alternativa aos desmandos da razão? Não teria Nietzsche, com sua radicalidade, ao tomar a vontade de potência, a criança como uma santa afirmação, caído em outro extremo e permanecido na metafísica? $\bigcirc$ que nos mostra Nietzsche? Respondendo a essas questões, podemos dizer que Nietzsche é um metafísico às avessas de Kant, é o outro do idealismo absoluto de Hegel, pois, ao invés de fundar sua referência na razão pura, funda-a na vontade pura, na "vontade de potência" como o princípio ativo afirmativo da vida, como o princípio do juízo. Mas, dessa forma, Nietzsche, que evidencia a autocontradição performativa do caráter apolíneo expresso no 
ideal racionalista, ao propor o elemento dionisíaco como referência, também cai em autocontradição performativa ${ }^{9}$, já que é autorreferenciado.

A fim de tornar mais evidente a argumentação tecida, citamos o argumento de Hermann (2001, p. 84) que, na obra Pluralidade e ética em educação, escreve: "o indivíduo kantiano, que necessita de sustentação moral, e o indivíduo nietzscheano que vive livremente seu destino sem um telos, respondem por diferentes conceitos de personalidade. [...] desse modo a personalidade fica contingente." Essa constatação, que tem profundo impacto, significa a dissolução de todos os referenciais de certeza tidos até então. Ocorre uma espécie de aniquilamento dos referenciais na medida em que ficam evidenciadas as contradições tanto de um quanto de outro, expondo o calcanhar de Aquiles das duas concepções, deixando o homem apenas como possibilidade. De outra forma, pode o paradigma estético constituir-se em alternativa aos desmandos do paradigma racionalista?

Mas, se com a estética, é possível ver e tocar os limites do paradigma racional, com a esteticização do mundo da vida, da própria ideia de verdade, corremos o risco de cair no outro extremo. E o que poderia constituir-se como sensibilidade, institui-se como insensibilidade, pois "[...] uma esteticização total leva em direção ao seu oposto. Onde tudo é belo, nada mais é belo; estimulação ininterrupta conduz ao embotamento; esteticização vira anestetização." (WELSCH, 1995, p. 18, grifo do autor). A sensibilidade fica cega, perde sua capacidade crítica, tornado-se incapaz de perceber os princípios desviantes. Isso porque, segundo a lei fundamental da estética descrita por Adorno (1970), nossa percepção, além de estímulo, precisa de descanso. Somente assim podemos chegar a uma sensibilidade desenvolvida capaz de perceber imperialismos, injustiças e desenvolver a luta pelos direitos dos oprimidos. (WELSCH, 1995). Assim, também, ficam expostos os limites do paradigma estético. Nessa perspectiva, quanto à educação, são sábias a palavras de Trevisan ao afirmar que,

[...] no momento em que é tencionado apenas um lado ou aspecto da polaridade que o divide, seja na afirmação, seja na negação da experiência dionisíaca exclusivamente, o trágico apresenta apenas a sua face perversa à educação. Em ambos os caso não temos o comparecimento do genuíno espírito da formação, mas apenas os efeitos nefastos de opções radicalizadas. (TREVISAN, 2011 , p. 303-304). 
Uma vez evidenciados e tocados os limites do paradigma racional que buscou libertar o homem das contingências, e os limites do paradigma estético em sua pureza, este que buscou libertar os sentidos, a sensibilidade do velho paradigma, perguntamos: como visualizar um horizonte sem que a humanidade caia na 'barbárie', tanto através da pura formalidade quanto da pura sensibilidade? As respostas a essa questão certamente já trouxeram ou trarão novas perspectivas à educação, pois é preciso, obrigatoriamente, considerar o elemento sensível, a contingência, como importante elemento constituinte dos processos educativos na tensão com a dimensão formal.

Respondendo ao engodo lançado a partir da reflexão sobre a entrada de Nietzsche no discurso filosófico da modernidade e suas implicações para educação, uma alternativa plausível a esse engodo é a proporcionada pela hermenêutica filosófica apresentada por Hans-Georg Gadamer (2005) que, a partir da compreensão da dimensão ontológica da obra de arte, evidencia a formação como autoformação no horizonte do acontecer intersubjetivo, como resposta aos desafios da ruptura da metafísica e ao empobrecimento da experiência, bem como à esteticização do mundo da vida. Por isso, no início de Verdade e método I: traços fundamentais de uma hermenêutica filosófica

196 (2005), Gadamer pergunta pelo significado do fim da metafísica e se aventura a pensar para além desta,

O que significa o fim da metafísica, enquanto ciência? $\bigcirc$ que significa o seu finalizar em ciência? Se a ciência se elevar até uma tecnocracia total, cobrindo o céu com a "noite do mundo" do "esquecimento do ser", o nihilismo predito por Nietzsche, será que devemos ficar olhando atrás do último brilho de sol que se pôs no céu noturno, em vez de voltar-nos e procurar olhar para as primeiras cintilações de seu retorno? (GADAMER, 2005, p. 25).

Sem ficar reclamando dos últimos lampejos da razão pura e nem perdido na pura vontade, Gadamer procura, em face da ruptura da metafísica, através do fundamento ontológico da obra de arte, resgatar o valor da tradição, articulando experiência estética e formação, ao mesmo tempo que apresenta a Hermenêutica Filosófica como fator corretivo. "Ela lança luz sobre o ponto de vista moderno do fazer, do produzir, da construção, plantados sobre pressupostos necessários, sob os quais ele próprio se encontra. Isso delimita especialmente a posição do filósofo no mundo moderno $[\ldots]^{\prime \prime}$ 
(GADAMER, 2005, p. 25), pois, nesse processo, o ser do sujeito que conhece também entra em jogo, o que expõe os limites do "método" científico, "[...] mas não o da ciência." (GADAMER, 2005, p. 6311 ).

\section{Considerações finais}

Com base no princípio estético dionisíaco, Nietzsche analisa o paradigma ocidental desde sua expressão moderna, identificando, no princípio estético apolíneo, o princípio estruturador do paradigma ocidental que sustentou o ideal de homem racional, o paradigma racional como referência, paradigma esse que este estava inviabilizando o ser. Assim, Nietzsche, ao abandonar o projeto da modernidade, ao criticar toda a tradição socrático-platônica-cristã e conferir autonomia ao deus Dionísio provoca uma reestruturação da tradição filosófica. Abre o debate da filosofia e educação contemporâneas, visto que seu pensamento lança e dá força ao paradigma estético, conferindo espaço às diversidades. Porém, como nos mostram Adorno (1 970) e Welsch (1995), a estimulação ininterrupta, pela qual descambou a estética contemporânea impossibilita e até impede a sensibilidade reflexiva. Assim, o desafio contemporâneo está em ter que reconsiderar os desacertos expressos na modernidade tais como a "[...] a separação entre entendimento e sensibilidade, a repressão da diferença e a afirmação do pensamento objetificador [...]" (HERMANN, 2010 , p. 13); em reconsiderar a articulação entre os deuses Apolo e Dionísio pelo impulso lúdico, na maioria das vezes, considerados como contraditórios, situação em que a educação perde cada vez mais seus vínculos com a cultura e com o mundo da vida.

As proposições filosóficas contemporâneas constituem-se, em grande parte, a partir das provocações de Nietzsche, potencializando ou até mesmo negando as provocações de Nietzsche, ou, de alguma forma fazem referência a Nietzsche. Por isso, atentamos para o perigo da autocontradição performática, tanto no âmbito do paradigma racionalista, com grande mérito para Nietzsche, como no âmbito do paradigma esteticista, com grande mérito para Adorno entre outros. É por esses motivos que anteriormente lançaram-se as perguntas: $\bigcirc$ que Nietzsche nos mostrou? $\bigcirc$ que é possível ver com Nietzsche e que não pode ser desconsiderado? Certamente, a pluralidade de valores, a impossibilidade de ideais e métodos absolutos, a educação como um 
acontecer temporal, pois o homem é temporalidade. Seus propósitos, desde então, não mais podem ser desconsiderados, tanto em níveis de ações mais reflexivas quanto em níveis de ações mais práticas.

Enfim, hoje, vivemos um tempo marcado pela crise paradigmática, em que não somente a ideia de verdade, os ideais educacionais entram em crise, como o próprio racionalismo clássico, em que a razão constitui-se como o referencial à certeza. Ao mesmo tempo, é o momento em que a própria razão passa a colocar-se na escuta do outro, reconhecendo-o enquanto outro (TREVISAN, 2000), conferindo novas perspectivas à formação. Assim, a filosofia e a educação contemporâneas trazem, em sua centralidade a emergência das diferenças, do outro enquanto outro, do eu enquanto eu, a intersubjetividade o reconhecimento de vontades de potência, um dos elementos à temporalidade da verdade que permitem a emergência e estruturação da filosofia da linguagem e a formação como autoformação.

\section{Notas}

$198 \quad 1 \quad$ anúncio da constatação da morte de Deus, realizado por Nietzsche, "[...] significa o fim do modo tipicamente metafísico de pensar." (GIACOIA JUNIOR, 2000, p. 24).

2 Sobre o modelo de perfeição, Descartes vale-se de Deus e das formas geométricas. "[...] sem alicerçar minhas razões em nenhum outro princípio, exceto no das perfeições infinitas de Deus (DESCARTES, 2004, p. 71) que, "[...] é esse Ser perfeito, é ou existe quanto seria qualquer demonstração de geometria." (DESCARTES, 2004, p. 71). Descartes crê num Deus como modelo de perfeição, modelo de razão. Assim, a partir da crença na perfeição divina e na ideia de que participamos desta perfeição, julgou, pela razão pura, a razão matemática, ser possível de conhecer as leis da natureza criadas pelo arquiteto supremo. Dessa maneira, para Descartes, o pensar corretamente é possível porque existe Deus, mas, ao mesmo tempo, a existência de Deus depende do pensar corretamente. Essa centralidade do eu foi profundamente questionada a partir de Nietzsche, cujo contexto é marcado pela "[...] desconstrução das éticas do dever ser, em especial da tradição iluminista." (HERMANN, 2001 , p. 69). Tal questionamento foi efetivado desde o predomínio das descobertas do caráter histórico da consciência através da experiência de finitude e de uma teoria de vontade de poder.

3 Ver o texto de $\bigcirc$ ensinamento do Além-do-Homem como ideal estético de Nietzsche de autoria de Roberto de Almeida Pereira de Barros e publicado pela revista Estudos Nietzsche, Curitiba, v. 2, n. 1, jan./jun. 2011 , p. 99-119.

4 "O caráter artístico dionisíaco não se mostra na alternância entre lucidez e embriaguez, mas sim em sua conjugação." (NIETZSCHE, 2005a, p. 10).

5 "Nenhuma vida teria subsistido, se não fosse sobre o fundamento de estimativas perspectivas e aparências." (NIETZSCHE, apud HERMANN, 2001, p. 78). 
6 "A estética da produção exibe a experiência do artista genial que cria valores: do seu ponto de vista as valorações são ditadas por um 'olhar que estabelece valores'." (HABERMAS, 2002, p. 177, grifo do originall.

7 Em $\bigcirc$ discurso filosófico da modernidade, Habermas afirma que o pensamento de Nietzsche desenvolveu-se como base na teoria da vontade de poder: "A teoria de uma vontade de poder que se apresenta em todo acontecer oferece o quadro em que Nietzsche explica como surgem as ficções de um mundo do ente e do bem e as ilusórias identidades dos sujeitos cognoscentes e moralmente agentes, como se constitui com a alma e a consciência de si uma esfera de interioridade, como a metafísica, a ciência e o ideal ascético passam a dominar e, enfim, como a razão centrada no sujeito deve todo esse inventário ao acontecimento de uma funesta inversão masoquista no mais íntimo da vontade de poder. A dominação niilista da razão centrada no sujeito é concebida como resultado e expressão de uma perversão da vontade de poder [...]" (HABERMAS, 2002, p. 139), pois conforme Nietzsche Em Assim falou Zaratustra lapud GIACOIA JÚNIOR, 2005, p. 58) diz: "Onde encontrei um ser vivente, lá encontrei vontade de poder. E, este mistério segredou-me a vida: 'Veja', disse ela, 'eu sou aquela que sempre tem de superar a si mesma'."

8 "A estética da produção exibe a experiência do artista genial que cria valores: do seu ponto de Sobe o perspectivismo ver o texto de Thiago Motaw Nietzsche e as perspectivas do perspectivismo, Thiago Motaw, publicado em Cadernos Nietzsche, 27, 2010.

9 Aqui é compreendida nos termos propostos por Karl-Otto Apel, em $\bigcirc$ desafio da crítica total da razão e o programa de uma teoria filosófica dos tipos de racionalidade. Ele afirma que uma crítica total da razão tal como pretendida pelos pós-modernos inspirados em Nietzsche é falha, porque fundada na vontade de poder como princípio, ou fundamentação última, está estruturada em círculo vicioso. Nas palavras de Apel (1989, p. 71, grifo do autor): "[...] as pressuposições do argumentar que podem ser vistas como princípios de fundamentação última são aquelas que não podem ser contestadas sem autocontradição performativa e, precisamente por isso, não podem ser fundamentadas logicamente sem círculo (vicioso) (petitio principii)". Mas há de se admitir que a crítica à racionalidade moderna, efetivada a partir da virada estética, especialmente por Nietzsche, tem o seu teor de verdade, por isso não podemos passar despercebidos por tal filósofo, uma vez que revelou o outro da razão moderna que se queria absoluta.

\section{Referências}

ADORNO, Theodor Wiesengrund. Teoria estética. Tradução Artur Morão. Lisboa [Portugal]: Edições 70, 1970.

APEL, Karl-Otto. O desafio da crítica total da razão e o programa de uma teoria filosófica dos tipos de racionalidade. Tradução Márcio Suzuki. Novos Estudos, São Paulo, n. 3, p. 67-84, mar. 1989.

AZEVEDO, Cristiane Almeida. $\bigcirc$ delirante Dionísio: o divino da vida a partir do trágico.

Aishte, Rio de Janeiro, n. 5, p. 18-30, 2010, Publicação semestral. 
BARROS, Roberto de Almeida Pereira de. $\bigcirc$ ensinamento do além-do-homem como ideal estético de Nietzsche. Estudos Nietzsche, Curitiba, v. 2, n. 1, p. 99-1 19, jan./jun. 2011.

DESCARTES, René. Discurso do método. Tradução Enrico Corvisieri. São Paulo: Nova Cultural, 2004. (Os Pensadores).

EURÍPEDES. As bacantes. Tradução Eudoro Souza. São Paulo: Hedra, 2010.

GADAMER, Hans-Georg. Verdade e método I: traços fundamentais de uma hermenêutica filosófica. Tradução Flávio Paulo Meurer. 7. ed. Petrópolis: Vozes; São Paulo/Bragança Paulista: Editora Universitária São Francisco, 2005.

Hermenêutica em retrospectiva: a virada hermenêutica. Tradução Marco Antônio Casanova. Petrópolis: Vozes, 2007. (v. 2).

GIACOIA JUNIOR, Oswaldo. Nietzsche. São Paulo, Publifolha. 2000.

Esclarecimento per(verso): Nietzsche à sombra da ilustração. Filos Aurora, Curitiba, v. 2, n. 27, p. 243-259, jul./dez. 2008.

HABERMAS, Jürgen. O discurso filosófico da modernidade. Tradução Luiz Sérgio Repa e Rodnei Nascimento. São Paulo: Martins Fontes, 2002.

200 HERMANN, Nadja. Pluralidade e ética em educação. Rio de Janeiro: DP\&A, 2001.

Ética e estética: horizonte em deslocamento. Veritas, Porto Alegre, v. 50, n. 2, p. 343-370, jun. 2004.

Unijuí, 2010.

Autocriação e horizonte comum: ensaios sobre a educação ético-estética. liuí:

ITAPARICA, André Luiz Mota. Nietzsche e a "superficialidade" de Descartes. Cadernos Nietzsche, São Paulo, n. 9, p. 67-77, 2000. (Publicação semestral).

KANT, Immanuel. Crítica da faculdade do juízo. Tradução Valério Rohden e Antonio Marques. Rio de Janeiro: Forense Universitária, 2008. (Traduzido da 2. ed. alemã de 1793).

MARQUES, Antônio. Sujeito e perspectivismo: seleção de textos de Nietzsche sobre teoria do conhecimento. Introdução e notas de Antonio Marques. Tradução Rafael Gomes Filipe. Portugal - Lisboa: Publicações Dom Quixote Lłda, 1989.

NASCIMENTO, Miguel Antonio do. O trágico, a moral, o fundamento. Cadernos Nietzsche, São Paulo, n. 4, p. 35-50, 1998. 
NIETZSCHE, Friedrich Wilhelm. Assim falava Zaratustra. Tradução Eduardo Nunes Fonceca. São Paulo: Hemus, 1985.

A gaia ciência. Tradução, notas e posfácio Paulo Cézar de Souza. São Paulo: Companhia das Letras, 2005.

A visão dionisíaca de mundo, e outros textos de juventude. Tradução Marcos Sinésio Pereira Fernandes e Maria Cristina dos Santos de Souza. Revisão da tradução de Marco Casanova. São Paulo: Martins Fontes, 2005a.

PLATÃO. A República. Tradução Enrico Corvisieri. São Paulo: Nova Cultural, 2004.

SCHILLER, Friedrich. Cartas sobre a educação estética da humanidade. Introdução e notas Anatol Rosenfeld. São Paulo: EPU, 1991.

TREVISAN, Amarildo Luiz. Filosofia da Educação: mímesis e razão comunicativa. liuí/RS: UNIJUÍ, 2000.

A experiência dionisíaca da formação no reconhecimento do outro. REP - Revista Espaço Pedagógico, Passo Fundo, v. 18, n. 2, p. 293-308, jul./dez. 2011.

WELSCH, Wolfgan. Esteticização e esteticização profunda ou: a respeito da atualidade do estético nos dias de hoje. Tradução Alvaro Walls. Revista Porto Arte, Porto Alegre, v. 6, n. 9, p. 7-22, maio. 1995.

Prof. Dr. Clenio Lago Universidade do Oeste de Santa Catarina | UNOESC| Joaçaba Programa de Pós-Graduação em Educação Grupo de Pesquisa Formação Docente e Práticas de Ensino E-mail | cleniolago@yahoo.com.br E-mail | clenio.lago@unoesc.edu.br

Recebido 3 jul. 2012 Aceito 14 ago. 2013 